\title{
LA PARTICIPACIÓN DE LAS VÍCTIMAS Y EL PRINCIPIO DE IGUALDAD DE ARMAS
}

\author{
THE PARTICIPATION OF VICTIMS AND THE \\ PRINCIPLE OF EQUALITY OF ARMS
}

María Isabel Santos Ramos*

\section{Resumen}

Con la promulgación de la Ley 906 de 2004 se implantó un sistema penal acusatorio, razón por la cual a la víctima se le concedieron escasos escenarios de participación encomendando la defensa de sus intereses a la Fiscalía General de la Nación. Por lo anterior, la Corte Constitucional, con el fin de asegurar la protección de los derechos de las víctimas a la verdad, la justicia y la reparación, les concedió ciertas prerrogativas que se concretan en una participación activa y directa en el proceso, lo cual genera una vulneración del principio de igualdad de armas entre acusador y acusado. Por ello, en este trabajo se pretende encontrar el punto medio en donde la balanza no se incline a favor de este interviniente especial y en disfavor de una de las partes que conforman la contienda.

\section{Palabras claves}

Víctima, participación, igualdad de armas, partes, proceso penal acusatorio.

\begin{abstract}
With the enactment of Law 906 of 2004, an accusatory criminal system was introduced, which is why the victim was granted few participation scenarios by entrusting the defense of his interests to the Attorney General's Office. Therefore, in order to ensure the protection of victims' rights to truth, justice and reparation, the Constitutional Court granted them certain prerogatives that involve active and direct participation in the criminal process. Which generates a violation of the principle of equality of arms between accuser and accused. Therefore, this paper seeks to find the middle point where the balance does not lean in favor of this special intervener and in disfavor of one of the parties that make up the contest.
\end{abstract}

\section{Keywords}

Victim, participation, equality of arms, parts, accusatory criminal proceedings.

\footnotetext{
* Magistrada Auxiliar de la Corte Suprema de Justicia, Sala de Casación Penal; Maestra en Derecho de la Universidad Sergio Arboleda.
} 


\section{Introducción}

A partir del Acto Legislativo 03 de 2002, por medio del cual se modificaron los artículos 116, 250 y 251 de la Constitución Nacional, y, con la consecuencial promulgación de la Ley 906 de 2004, se implantó en nuestro país un sistema procesal penal acusatorio que se caracteriza, principalmente, por la separación entre las funciones de investigación y acusación y la de juzgamiento; el control judicial de la limitación de derechos fundamentales por parte del juez de control de garantías; la instauración del principio de oportunidad; el juicio orientado por los principios de oralidad, contradicción, inmediación y publicidad; y, por último, sin que ello signifique que sea menos importante, un procedimiento que reconoce al acusador y al acusado la condición de partes iguales, razón por la que a la víctima se le concedían escasos escenarios de participación y se encomendó la defensa de sus intereses a la Fiscalía General de la Nación.

Frente a la anterior realidad, la Corte Constitucional, con el fin de asegurar la protección efectiva de los derechos constitucionales de la víctima a la verdad, la justicia, la reparación y al acceso a la administración de justicia, le reconoció derechos y facultades que no estaban plasmados en la Ley 906 de 2004, los cuales se concretan en una participación activa y directa en la contienda. Así, por ejemplo, se le permite presentar solicitudes probatorias en la audiencia preparatoria, pedir la práctica de pruebas anticipadas ante el juez de control de garantías y participar en el descubrimiento probatorio, entre otras facultades.

Lo anterior genera una disyuntiva, pues, por un lado, se tiene a una víctima que interviene de forma directa y activa en el proceso penal para asegurar la garantía de sus derechos a la verdad, la justicia y la reparación (principio del libre acceso a la administración de justicia); y, por el otro, está el marco de un proceso penal adversarial, constituido de forma primordial como un sistema de garantías que opera a partir del principio rector de la igualdad de armas entre acusador y acusado. Ello obliga a preguntarse si la intervención de la víctima en el proceso penal nacional, tal y como está concebida en la actualidad, vulnera el principio de igualdad de armas.

A fin de resolver el problema jurídico planteado con esa pregunta, el objetivo principal de esta incursión académica es determinar si la intervención de la víctima de manera activa y directa en el proceso penal colombiano, vulnera o no el principio de igualdad de armas. Además, se persiguen los siguientes objetivos específicos: conocer el concepto del principio de igualdad de armas; analizar las decisiones proferidas por la Corte Constitucional por medio de las cuales le otorga facultades a la víctima para intervenir de manera activa y directa en el proceso penal; determinar cuáles son las facultades de la víctima en el proceso penal acusatorio adoptado; conocer las posiciones doctrinales acerca de la intervención de la víctima en la contienda. También, establecer si dichas facultades atentan contra el principio de igualdad de armas y evaluar el grado de vulneración del mismo con el ejercicio de las facultades otorgadas; finalmente, sugerir una regla en cuya virtud se logre encontrar el equilibrio entre los derechos de las víctimas a interve- 
nir en el proceso y el principio de igualdad de armas y, así, evitar que la balanza se incline a favor de este interviniente especial y en disfavor de una de las partes que conforman la contienda. Todo ello, obliga a hacer un verdadero test de proporcionalidad o de razonabilidad, a manera de guía metodológica para, como dice la Corte Constitucional,

[d]ar respuesta a la tercera pregunta que debe hacerse en todo problema relacionado con el principio de igualdad: ¿cuál es el criterio relevante para establecer un trato desigual? o, en otras palabras, ¿es razonable la justificación ofrecida para el establecimiento de un trato desigual? (Sentencia C-022 de 1996).

Para ello, en primer lugar, y con base en una metodología analítica deductiva y crítica, se aborda el origen y el concepto del principio de igualdad de armas, a cuyo efecto se examinan algunas sentencias del Tribunal Europeo de Derechos Humanos; también se miran los aportes de doctrinantes internacionales sobre el asunto. Y, por supuesto, la noción que brindan la Corte Constitucional, la Sala de Casación Penal de la Corte Suprema de Justicia y los autores colombianos; para finalizar, se emite un concepto propio.

Luego, en segundo lugar, se examina la postura asumida por la Corte Constitucional para quien las amplísimas facultades otorgadas a la víctima no generan una desigualdad de armas ni alteran los rasgos fundamentales del sistema penal con tendencia acusatoria, ni implican una transformación del papel de interviniente especial que ella tiene dentro del sistema procesal penal; antes por el contrario, se dice, garantizan no solo que las normas encargadas de regular lo concerniente a su participación tomen en cuenta sus derechos a la verdad, la justicia y la reparación, amén de la existencia de mecanismos idóneos para asegurar su protección efectiva.

Se destaca que la posición asumida por la Corte Constitucional no es aceptada de manera pacífica por la comunidad jurídica, por lo cual se estudian las posturas asumidas por algunos autores que la respaldan mientras que, para otros, la Constitución Nacional fue tímida al negarle la posibilidad a la víctima de participar en el juicio oral; $y$, en fin, otros para quienes concederle amplias facultades de intervención es del todo contraproducente.

En tercer lugar, se asume una postura crítica en relación con las posiciones doctrinales y jurisprudenciales respecto de la intervención de la víctima en el proceso penal y se concluye que los esfuerzos de la Corporación, al ponderar los derechos de las víctimas y el principio de igualdad de armas fueron equívocos, pues, terminaron por inclinar la balanza a favor de aquella y en disfavor del acusado, lo cual se traduce en una vulneración al principio de igualdad de armas. Por ello, al final de este acápite se propone una subregla llamada a ser aplicada al momento de analizar la posibilidad de intervención de la víctima de manera activa y directa en el proceso, sin que por ello se genere una vulneración del principio de igualdad de armas. Para culminar, se consignan las conclusiones de la investigación y se recogen las referencias donde se consigna el material bibliográfico consultado. 


\section{El principio de igualdad de armas}

Uno de los orígenes del principio de igualdad de armas es el diseño procesal norteamericano (Roviaro vs. United States, 1957; con antecedentes en Sorrentino vs. United States, 1947; United States vs. Conforti, 1953; Portomene vs. United States, 1955); en esa oportunidad, la Corte Suprema de ese país estableció que, en aplicación del principio de equidad procesal (fairness), la fiscalía estaba obligada a revelar la identidad de un agente encubierto que había estado presente en el momento en que tuvieron ocurrencia los hechos investigados, siempre que ello fuera pertinente y útil para la defensa del acusado o esencial para un juicio justo. Posteriormente, en otros casos (Brady vs. Maryland, 1963; United States vs. Agurs, 1976; Giglio vs. United States, 1972; United States vs. Bagley, 1985; Kyles vs. Whitley, 1995, entre otros), esa misma corporación judicial extendió los alcances del principio, buscando que la Fiscalía revelara información y evidencia relevantes para la defensa, siempre que existiera una probabilidad razonable de que, si la evidencia no era descubierta, el resultado del juicio se viera afectado sin que ello significara desplazar al sistema adversarial como el principal medio por el cual se descubre la verdad sino, por el contrario, asegurar que no se produjera un error en la administración de justicia.

De otro lado, en Alemania, el concepto de igualdad de armas o Waffengleichheit (Roxin, 2000, pp. 80-81) apareció por primera vez en la mitad del siglo XIX, en escritos legales durante las discusiones generadas alrededor de la reforma fundamental del proceso criminal alemán (Esparza, 1994, pp. 175 y ss.). Posteriormente, a mediados del siglo XX, la antigua Comisión Europea de Derechos Humanos introdujo el término de igualdad de armas por primera vez; en los casos examinados, el punto de unificación fue que al acusado no se le había dado la oportunidad de ser escuchado, a diferencia de lo ocurrido con la parte contraria. En consecuencia, la Comisión precisó que "la igualdad de armas, es la igualdad procesal del acusado con el acusador público, es un elemento inherente al juicio justo" (Resolución DH(63)1, Ofner and Hopfinger vs. Austria, 1963; Report No. 31/63, Pataki and Dunshirn vs. Austria, 1963).

No obstante, hay quienes entienden que el postulado de igualdad de armas es una expresión del viejo principio de audiatur et altera pars o, de forma más simple, "Hear the other side of the question; listen to what each party may be able to advance, otherwise you cannot be sure that your decision will be impartial or just" [escuchar el otro lado del asunto. Escuchar lo que la otra parte puede ser capaz de avanzar, de lo contrario, no puedes estar seguro que su decisión será justa o imparcial] (Moore, 1831, p. 30). Sin embargo, el Tribunal Europeo de Derechos Humanos -TEDH- ha deducido el principio de la igualdad de armas del postulado del juicio equitativo contenido en el párrafo $1^{\circ}$ del artículo $6^{\circ}$ del Convenio Europeo de Derechos $\mathrm{Hu}$ manos (Neumeister vs. Austria, 1968; Delcourt vs. Bélgica, 1970); ese organismo aseveró, de manera coincidente, que el principio de igualdad de armas o de igualdad de trato se encuentra incluido en el concepto de proceso equitativo mencionado en el artículo 6-1 de la Convención Europea de Derechos Humanos, que se constituye en una manifestación del concepto más amplio de un juicio justo ante un tribunal independiente e imparcial. 
Por supuesto, también con posterioridad, se observan importantes desarrollos en esta materia en diversos casos (Abramovich, 2007, pp. 51-52). En efecto, el Tribunal definió el principio de igualdad de armas en otras decisiones (Bulut vs. Austria, 1996; Lanz vs. Austria, 2002; y Fischer vs. Austria, 2002) como parte de un concepto más amplio de fair trial, por medio del cual se garantiza a cada parte una oportunidad razonable para presentar su caso en condiciones que no la pongan en desventaja, vis-à-vis con su oponente. Incluso, en otros pronunciamientos (Brandstetter vs. Austria, 1991 y Öcalan vs. Turquía, 2005), ese mismo organismo indicó que dicho principio se materializa en la oportunidad que deben tener el acusador y la defensa de conocer las observaciones y las evidencias aportadas por la otra parte, $y$, así, poder discernir sobre ellas.

La doctrina también estudia el concepto de igualdad de armas. En este sentido, se concibe el sistema acusatorio como una relación tríadica entre tres sujetos: el acusador, el defensor y el juez, siendo este último un sujeto pasivo rígidamente separado de las partes; y, el juicio, como una contienda que se desarrolla lealmente y con igualdad de armas, lo cual se traduce en que la defensa esté dotada de la misma capacidad y de los mismos poderes de la acusación, admitiéndose su poder contradictor en todo momento y grado del procedimiento y en relación con cualquier acto probatorio (Ferrajoli, 2009, p. 614). No obstante, algún sector del pensamiento procesal alemán parece proclive a no aludir a una igualdad de armas, porque "hoy ya no se puede hablar de igualdad de armas entre imputado y ministerio público, sino de una relación equilibrada entre derechos y deberes de ambos" (Baumann, 1986, p. 35).

Por su parte, un reputado expositor hispano sostiene que el principio de igualdad de armas es una proyección del genérico axioma de igualdad, que debe estimarse vulnerado cuando el legislador crea privilegios procesales a favor de una parte, carentes de fundamentación constitucional alguna, o cuando el mismo hacedor de las leyes o el órgano jurisdiccional crean posibilidades que se le niegan a la parte contraria, o, en fin, cuando a alguna de las partes se les imponen cargas procesales desorbitadas "sin justificación objetiva o razonable alguna" (Gimeno, 2007, p. 58).

Es que, como se ha dicho, la igualdad de armas exige que las partes puedan presentar su caso bajo condiciones que no constituyan una posición desventajosa frente a su contraparte, principio que cobra un significado especial cuando se trata de interpretar los derechos del imputado (Ambos, 2005, p. 67). Así las cosas, la fairness, que se traduce como equidad, significa que el proceso en donde tiene lugar la dialéctica adversarial entre quien acusa y quien se defiende de la acusación, debe producirse sin trampas, oscurantismos o indefensiones; esto es, de manera justa, equilibrada, equitativa e imparcial (Gómez, 2008, p. 48).

De otra parte, la doctrina alemana se refiere al principio de igualdad de armas como aquel mandato que exige una posición lo más equilibrada posible de los intervinientes en el procedimiento, lo anterior en atención a que dicha expresión 
[i]gualdad de armas no es del todo realizable, pues una verdadera igualdad de armas no sería compatible con nuestra estructura de procedimiento, ni tampoco sería realizable en un proceso de partes puro ( $¿$ Debe acaso el imputado tener el derecho de conducir él mismo el examen corporal de un testigo de descargo?). Sin embargo, el mandato del fair trial puede prohibir, p. ej., una limitación de los derechos de información y de participación del imputado o de su defensor, no cubiertas por las diferencias lógico-objetivas entre el papel del acusador y el del defensor en particular, sin que con ello se haga alusión a una igualdad de armas en sentido formal (Roxin, 2000, pp. 80-81).

Este criterio coincide con lo expuesto por la doctrina argentina, para la cual la igualdad de armas, concebida como la equiparación de las posibilidades del imputado respecto de aquellas que poseen los órganos de persecución penal del Estado en el proceso penal, es un ideal, quizá utópico, pues considera que quien ejerce el poder penal del Estado dispone de medios que son difíciles de equiparar. Sin embargo, de lo que se trata es de

acercarse en la mayor medida posible al proceso de partes, dotando al imputado -aún de manera parcial-, de facultades equivalentes a las de los órganos de persecución del Estado y del auxilio procesal necesario para que pueda resistir la persecución penal, con posibilidades parejas a las del acusador (Maier, 2004, p. 578).

E, incluso, existen posiciones más radicales como la plasmada en la Exposición de Motivos del Código de Procedimiento Penal italiano de 1930, según la cual

[n]o es admisible el principio que equipara al ministerio fiscal con el imputado, hasta exigir que a cada facultad del primero corresponda una facultad del segundo. Este principio desciende de un concepto de igualdad que, si puede admitirse en el proceso acusatorio puro, en el que acusador e imputado son personas privadas, es manifiestamente erróneo en el derecho procesal vigente, en el que el acusador es un órgano público (Ferrajoli, 2009, p. 615).

En nuestro país, el principio de igualdad de armas -o igualdad de partes- ha sido reconocido ampliamente en la Ley 906 de 2004:

Es obligación de los servidores judiciales hacer efectiva la igualdad de los intervinientes en el desarrollo de la actuación procesal y proteger, especialmente, a aquellas personas que por su condición económica, física o mental, se encuentren en circunstancias de debilidad manifiesta $\left(\right.$ art. $4^{\circ}$ ).

$\mathrm{Y}$, el artículo $8^{\mathrm{o}}$ de la misma codificación, antes de enumerar los derechos de la defensa, preceptúa que "[e]n desarrollo de la actuación, una vez adquirida la condición de imputado, éste tendrá derecho, en plena igualdad respecto del órgano de persecución penal $[\ldots]^{\prime \prime}$.

Estas disposiciones, en esencia, recogen instrumentos internacionales como el previsto en el artículo 8 de la Convención Americana sobre Derechos Humanos que prevé el derecho general a la defensa, como se infiere del párrafo $1^{\circ}$ que desarrolla dicho derecho para todo tipo de procesos y, en especial, de los incisos $2^{\circ}$ a $5^{\circ}$, específicamente para el proceso penal. Del derecho general de defensa se derivan 
derechos como el de igualdad o equidad procesal (también llamado igualdad de armas) y el de audiencia previa (Rodríguez, 1998, p. 1305). Las mismas, han sido explicadas por la Corte Interamericana de Derechos Humanos y la Comisión Interamericana de Derechos Humanos (Abramovich, 2007, pp. 51 y ss.).

A su turno, la jurisprudencia (Corte Constitucional, sentencias C-1194, 2005; C-118, 2008 y C-536, 2008), se refiere al principio de igualdad de armas dentro del proceso penal para indicar que es un mandato de carácter constitucional derivado no solo del artículo 13 de la Constitución Nacional, sino, también, del Acto Legislativo 03 de 2002 y de los artículos 29 y 229 de la Carta, que se constituye en una característica esencial de los sistemas penales de tendencia acusatoria según el cual "las partes deben contar con medios procesales homogéneos de acusación y defensa, de tal manera que se garanticen las mismas posibilidades y cargas de alegación, prueba e impugnación" (Sentencia C-396, 2007) buscando, con ello, garantizar que el acusador y el acusado tengan a su alcance opciones reales y ciertas para ejercer sus derechos, así como las herramientas necesarias para situarse en un equilibrio de potestades y atribuciones en aras de hacer respetar sus pretensiones e intereses.

La misma Corporación señala que el principio de igualdad de armas hace parte del núcleo esencial de los derechos de defensa, de contradicción, y, más ampliamente, del principio del juicio justo, el cual es desconocido cuando el legislador concede cierto privilegio o ventaja exclusiva a una de las partes, con la potencialidad de reflejarse en los resultados del proceso (Corte Constitucional, sentencia C-616, 2014); pero, además, en todos aquellos supuestos en que "la ley conduce a fortalecer numérica o sustantivamente uno de los dos protagonistas de la controversia, pues ello anula las posibilidades de un juicio equitativo y justo y de una asistencia técnica eficaz" (Sentencia C-473, 2016).

Por su parte, la Sala de Casación Penal de la Corte Suprema de Justicia, describe el principio de igualdad de armas como un bastión fundamental del sistema acusatorio, que se encarga de ofrecer a las partes medios adecuados para que su labor, de conformidad con el rol que se ejerce, "no se vea obstaculizada por medidas discriminatorias o limitaciones logísticas y económicas que desequilibren la balanza a favor de la contraparte" (Sentencia radicado 29118, 2008), y que se encuentra vinculado con el debido proceso probatorio, pues permite garantizar que las partes "gocen de idéntica oportunidad de obtener, solicitar, recaudar los elementos materiales probatorios, evidencia física e información legalmente obtenida que puedan servirle de base de la respectiva teoría del caso a demostrar durante el debate oral" (Auto 39449 de 2013).

Ahora bien, algunos expositores patrios manifiestan que la igualdad de armas es la concreción del presupuesto de la igualdad relativa, que reconoce iguales oportunidades y similares potestades a las partes en el proceso, y que se concreta en igualdad de oportunidades para recoger evidencia y potestades similares a las partes. Señalan que dicha situación relacional debe abordarse desde dos perspectivas: una, estrictamente formal, esto es, que todas las partes tienen la oportunidad 
de presentar su versión de la realidad, aportar pruebas y hacerse oír por un juez. Y, otra, material, es decir, la existencia de un diálogo realizado entre partes con iguales oportunidades para recabar información y evidencias que soporten sus alegatos (Bernal \& Montealegre, 2013, pp. 205 y 613). En el mismo sentido, se señala que la igualdad implica que "las partes procesales estén en perfecto equilibrio frente a la jurisdicción y que no se den tratamientos parcializados, ventajosos o discriminatorios en detrimento de la persona del sindicado" (Fernández, 1999, pp. 161-162).

Es más, se expresa que

Un proceso caracterizado como "fair trial" conserva entonces la peculiaridad de ser contradictorio entre los adversarios, y la igualdad de armas se expresa en la posibilidad de que ambos puedan presentar el caso en los hechos y el Derecho, proponer las pruebas que fundan sus tesis y contradecir al oponente (Guerrero, 2005, p. 104).

De conformidad con lo expuesto, entonces, el principio de igualdad de armas es una característica esencial del sistema de enjuiciamiento penal acusatorio mediante el cual se garantiza que las partes, esto es, acusador y acusado, se enfrenten ante un tercero imparcial, que es el juez, con las mismas herramientas y posibilidades, sin privilegios ni desventajas, a fin de convencerlo de su particular pretensión. Ello es fundamental para entender el papel de la víctima al interior de la estructura del proceso penal adoptada, tal como se muestra enseguida.

\section{La intervención de la víctima en el proceso penal acusatorio colombiano}

Según se desprende de las ponencias presentadas en el Congreso con ocasión del trámite del Proyecto de Acto Legislativo 237 2002, que generó la promulgación del Acto Legislativo 03 de 2002, por medio del cual se modificó al artículo 250 de la Constitución Nacional (Gaceta del Congreso No. 134, 2002), el legislador consideró que, al instaurarse un modelo procesal de tendencia adversarial, caracterizado por el principio de igualdad de armas, la víctima no debía participar de manera directa en su desarrollo, por cuanto el litigio se trababa únicamente entre el Estado y el imputado. Por ello, a la víctima se le concedían escasos escenarios de participación y se encomendaba la defensa de sus intereses a la Fiscalía General de la Nación, a quien el artículo 250 de la Constitución Nacional le confiaba "solicitar al juez que ejerza las funciones de control de garantías las medidas necesarias que aseguraran la comparecencia de los imputados al proceso penal, la conservación de la prueba y la protección de la comunidad, en especial de las víctimas" (Artículo 250, numeral $1^{\circ}$ ). Así mismo, "solicitar ante el juez de conocimiento las medidas judiciales necesarias para la asistencia de las víctimas, lo mismo que disponer el restablecimiento del derecho y la reparación integral a los afectados con el delito" (idem, numeral $6^{\circ}$ ); y, por último "velar por la protección de las víctimas, los jurados, los testigos y demás intervinientes en el proceso penal, la ley fijará los términos en que podrán intervenir las víctimas en el proceso penal y los mecanismos de justicia restaurativa" (ibidem, numeral $7^{\circ}$ ). Estos postulados constitucionales encontraron su desarrollo, principalmente, en los artículos 11,114 numerales $6^{\circ}, 8^{\circ}, 12^{\circ}$, y 132 a 137 de la Ley 906 de 2004. 
A lo anterior se debe añadir que también el legislador propicia nuevos espacios para la intervención de la víctima en el proceso penal como sucede ahora, luego de expedida la Ley 1826 de 2017, que posibilitará que las propias víctimas puedan interponer de forma privada la acción penal, previa autorización por parte de la Fiscalía General de la Nación; estos mecanismos de participación privada en el proceso penal no están exentos de críticas como sucede, verbi gratia, por parte de comentaristas de legislaciones como la chilena (Horvitz y López, 2004, p. 538), aunque la doctrina reciente aboga por una mayor protección de la víctima al interior del proceso penal en este y en todos los frentes (Duce, 2014, pp. 740 y ss.). No obstante, en otras naciones como España es más pacífica su introducción (Chocrón, 2008, pp. 693 y 697; De Vicente, 1997, pp. 173 y ss.).

Sin embargo, la jurisprudencia, con el fin de asegurar la protección efectiva de los derechos constitucionales de la víctima a la verdad, la justicia y la reparación $y$, en consecuencia, al acceso a la administración de justicia, le ha reconocido derechos y facultades que no venían consignados en la Ley 906 de 2004, los cuales se han concretado en una participación activa y directa en la contienda (Corte Constitucional, sentencia C-228, 2002).

Así, la víctima se encuentra facultada para solicitar, en audiencia preliminar ante el juez con funciones de control de garantías, la práctica de pruebas anticipadas y la imposición de medidas de aseguramiento en contra del imputado. También, en la audiencia de formulación de acusación puede efectuar observaciones al escrito de acusación o manifestarse sobre posibles causales de incompetencia, recusaciones, impedimentos o nulidades, y solicitar al juez de conocimiento el descubrimiento de un elemento material probatorio específico o evidencia física específica. En la audiencia preparatoria, puede realizar solicitudes probatorias, hacer observaciones sobre el descubrimiento de elementos materiales probatorios y de la totalidad de las pruebas que se harán valer en la audiencia de juicio oral; incluso, está habilitada para solicitar la exhibición de los elementos materiales probatorios y de evidencia física para que sean conocidos y estudiados; y pedir la exclusión, el rechazo o la inadmisión de los medios de prueba y solicitar la conexidad procesal. Para terminar, en el juicio oral, puede presentar alegatos finales por intermedio de su abogado; facultades todas estas que puede ejercer de manera directa al interior del proceso penal, como si se tratara de una parte y no de un 'interviniente especial' como lo llama la ley procesal.

Lo anterior genera, entonces, la siguiente disyuntiva: por un lado, aparece una víctima que interviene de manera directa y activa en el proceso penal, para garantizar sus derechos a la verdad, a la justicia y a la reparación; y, por el otro, se preconiza la implantación de un proceso penal adversarial, constituido como un sistema de garantías, que opera bajo el principio rector de igualdad de armas entre acusador y acusado. Ello, justo es decirlo, es lo que obliga a preguntarse si la intervención de la víctima así entendida vulnera o no el principio de igualdad de armas.

Pues bien, para la Corte Constitucional las amplísimas facultades otorgadas a la víctima por medio de su jurisprudencia no generan desigualdad de armas ni 
alteran los rasgos fundamentales del sistema penal con tendencia acusatoria, ni, tampoco, implican una transformación del papel de interviniente especial dentro de nuestro sistema procesal penal; antes, por el contrario, sostiene que, no solo garantizan que las normas que regulan lo concerniente a la participación de las víctimas tomen en cuenta sus derechos a la verdad, la justicia y la reparación, sino la existencia de mecanismos idóneos para asegurar su protección efectiva.

Sin embargo, la Corporación reconoce que existe una clara tensión entre los derechos de las víctimas a intervenir de manera directa y activa en el proceso penal y los de las partes (fiscal y defensa) de participar en la contienda con igualdad de armas, razón por la cual señala que la participación de aquellas depende de los siguientes factores: a) el papel asignado a otros participantes, en particular a la fiscalía; b) el rol que les reconoce la Constitución; c) el lugar donde ha previsto, de forma específica, su participación y las características de cada una de las etapas de la actuación; y, d) la importancia de esa participación para sus derechos y la incidencia en la estructura y formas propias del sistema penal de tendencia acusatoria (Corte Constitucional, sentencia C-473, 2016).

Así, la Corte señala que la actuación directa e independiente de la víctima en la etapa del juicio oral se encuentra restringida en virtud del principio de igualdad de armas entre acusador y acusado, por lo cual, las atribuciones que no le son concedidas de forma independiente, pueden ser ejercidas a través del fiscal. Pero, en las etapas de la indagación y de la investigación formal, a ellas les asiste el derecho a recibir información y a intervenir de manera activa en todos los trámites sobre iniciación, continuación, terminación, suspensión, archivo y rumbo de las diligencias; igual sucede en las audiencias de formulación de acusación y preparatoria, dada la estrecha relación existente entre estas potestades y sus derechos a la verdad, la justicia y la reparación, salvo, se itera, al interior del juicio oral.

Pues bien, la postura asumida por ese organismo no es aceptada de manera pacífica por la comunidad jurídica, pues, aun cuando hay autores que la respaldan, existen otros que consideran que la guardiana de la Constitución Nacional fue tímida al negarle la posibilidad a la víctima de participar de manera proactiva en el juicio oral, y, unos más, creen que concederle amplias facultades de intervención a la víctima al interior del proceso penal es contraproducente. Por eso, se estima que el principio de igualdad de armas incluye no solo al ente acusador y a la defensa, sino, también, a la víctima, quien, sin lugar a discusiones, debe tener una participación activa en el proceso penal, para velar por la salvaguarda de sus intereses particulares -verdad, justicia, reparación y garantía de no repetición- y para la construcción de la verdad como fin último del proceso penal (Bernal \& Montealegre, 2013, pp. 205 y 216; Parra, 2010, pp. 374 y ss.).

En consecuencia, como quiera que la víctima no es un sujeto pasivo en el esquema procesal, debe permitírsele participar en el proceso penal, reconociéndosele la posibilidad de debatir o proponer fórmulas de reparación y de recuperación de la convivencia rota por la conducta punible (Bernal \& Montealegre, 2013, p. 717). En el mismo sentido, se asevera que el principio de igualdad de armas no se refiere 
a una cuestión cuantitativa sino cualitativa, que se relaciona con la posibilidad de que los 'actores o partes' gocen de las mismas oportunidades para intervenir y actuar en el proceso penal, debiendo admitirse a la víctima 'como ejercitante autónomo e independiente de la acción privada o material', pues, en su sentir, en el proceso penal hay tres intereses en juego: "el del Estado como representante de la sociedad, el de la víctima y el del procesado" (Cerón, 2008, p. 205), motivo por el cual la víctima debe estar en igualdad con los otros partícipes de la actuación, para satisfacer sus interés particulares. Por ello, su intervención no vulnera el principio de igualdad de armas, pues ella no interfiere con la actividad procesal del acusado, sino que, por el contrario, es el mismo axioma el que aconseja otorgarle plenas facultades, dado que ella debe ser considerada una verdadera parte (Cerón, 2008, p. 204). Es más, otro expositor afirma que

[u)na de las aspiraciones del legislador colombiano con la Ley 906, ha sido el poder implantar los derechos de la víctima en el proceso penal, dándole una amplia participación como sujeto procesal, como participante activo y con facultades para intervenir en la solución del conflicto originado con el delito (Márquez, 2006, p. 150; Márquez, 2009, p. 33).

Otros, desde una perspectiva más amplia, aseguran que un sistema penal que quiera ser coherente con el modelo de Estado social y democrático de Derecho debe propender por la humanización del sistema penal y, para lograrlo, debe orientarse hacia las víctimas, reconociéndoles un verdadero protagonismo y atender sus derechos, garantías y necesidades, pues, en su sentir, las escasas o inexistentes alternativas legales para la intervención de ella en el proceso penal "son factores, entre otros, que han hecho del sistema penal un verdadero laberinto para las víctimas en el cual se sienten perdidas, estigmatizadas y olvidadas" (Sampedro, 2008, p. 357). De ahí que también se afirme: "no puede concebirse un proceso penal con exclusión de las víctimas, pues son ellas las primeras en ser llamadas a vindicar sus derechos" (Sampedro, 2012, p. 133).

Por otra parte, contrario a lo expuesto por la Corte Constitucional, se asevera que la reforma introducida mediante el Acto Legislativo 03 de 2002 no implica que se haya implantado un sistema procesal penal adversarial, por lo cual es infundado que "por rendirle culto a una supuesta característica de un sistema acusatorio, se terminen restringiendo los derechos de las víctimas, derechos estos sí debidamente regulados y supuestamente amparados desde la Constitución Política" (Gaviria, 2015, p. 467). Se estima, además, que las interpretaciones de la Corte Constitucional acerca de la participación de la víctima en el proceso penal son insuficientes y que, además, debe reconocérsele la posibilidad de participar de manera directa y activa en el juicio, pues lo contrario imposibilita obtener una decisión acorde con sus intereses (p. 470).

Se asegura, en fin, que la Corte Constitucional es contradictoria en su postura, pues, por un lado, de manera enfática y reiterada señala que "el nuevo sistema procesal en manera alguna puede limitar los derechos de la víctima a reparación, verdad y justicia", sin embargo, concluye que, en virtud del principio adversarial, 
"los derechos de las víctimas sí encuentran claras limitaciones, particularmente en la etapa del juicio, por cuanto de permitirse una participación activa de ellas en el debate probatorio se resentiría gravemente el principio de igualdad de armas" (Gaviria, 2009, p. 37), lo que a todas luces comporta un desconocimiento y olvido de los derechos que le han sido reconocidos a las víctimas.

En el mismo sentido, se escribe que "la participación de la víctima debe ser continua, sin interrupciones, en toda la actuación penal, tanto en la etapa de investigación como en las audiencias que componen el juicio oral" (Vanegas, 2008, pp. 376-381). Por ello, para este último autor resulta un contrasentido que la Corte Constitucional le permita a la víctima participar en las audiencias de formulación de acusación y en la preparatoria para solicitar la práctica de pruebas, y, luego, le niegue su intervención en el juicio oral para presentar su teoría del caso y participar en su práctica, lo cual es un retroceso en el reconocimiento de sus derechos fundamentales.

De otro lado, también se cree que la única manera de garantizar la efectividad de los derechos de las víctimas no es con su intervención activa y directa en el proceso penal, pues esas metas pueden ser alcanzadas a través de otros mecanismos. Es más, se asegura que la discusión sobre su participación no debe plantearse como un problema derivado del derecho a la igualdad, a menos que se entienda dicho axioma desde un punto de vista puramente aritmético; por ello, "el principio de igualdad debe entenderse, en sentido sustancial, como la facultad que tiene cada parte procesal a disponer de los mismos derechos y deberes reconocidos a las demás partes procesales, con absoluta independencia de cuántas sean esas últimas" (Reyes, 2007, p. 77). Luego, entonces, siempre que las partes (fiscal, ministerio público y defensa) gocen de las mismas oportunidades para sustentar sus tesis dentro del respectivo proceso, no se afectará la vigencia del principio de igualdad de armas.

Por consiguiente, para el autor en cita el aspecto sensible radica en que el legislador escogió a la Fiscalía General de la Nación como la entidad encargada de investigar y acusar a los presuntos responsables de la comisión de delitos, por lo cual "las víctimas del delito deban canalizar a través de esa institución todas las solicitudes que quieran hacer a los jueces penales y no solamente aquella relacionada con la acusación misma" (Reyes, 2007, p. 79); en consecuencia, permitir que ellas participen en las audiencias, equivaldría a despojar a la fiscalía del monopolio sobre las funciones de investigar y acusar a los presuntos responsables por la comisión de conductas punibles. Sobre el tema, también se asegura que, si bien la ley propicia el reconocimiento y protagonismo a la víctima en atención a los desarrollos jurisprudenciales, doctrinales y con la normativa internacional, lo cierto es que algunas disposiciones tienen como efecto inclinar la balanza en su favor, "situación que rompe el equilibrio que debe darse para que exista la igualdad de armas en el desarrollo del debate. De ninguna manera los intereses de la víctima pueden estar por encima de los que corresponden a los justiciables" (Sánchez, 2004, pp. 107 y ss.). 
Es más, otro sector doctrinario estima que un sistema acusatorio puro parte de la existencia de un organismo que se encarga de investigar y acusar que se enfrenta en plano de igualdad a la defensa ante un juez imparcial, por lo cual no se admite la presencia y/o participación de otros sujetos o partes en la contienda, pues ello generaría un desequilibrio. Se dice, en efecto, que "un procesal real y verdaderamente acusatorio, no tiene por qué (ni cómo) reconocer o admitir en su seno a los perjudicados que pretenden reclamar la indemnización de los daños que les han sido irrogados con la materialización del comportamiento delictivo" (Molina, 2010, p. 166). Otro expositor, en la misma línea de análisis, manifiesta que la actuación de la víctima en todas las audiencias que se realizan durante la investigación y el juzgamiento, inclina la balanza en contra del procesado, lo cual resulta inadmisible; si bien, reconoce que 'este interviniente especial' también busca la verdad y la justicia, su interés debe surtirse por conducto de la Fiscalía General de la Nación, y no convertirla en otra parte más de la contienda, de donde surge que "es importante restringir su intervención al logro de una reparación integral cuando allí proceda" (Daza, 2009, p. 142).

Desde luego, tampoco faltan voces para las cuales se debe tener mucho cuidado con esta ingerencia de la víctima al interior del proceso penal y entienden que se deben dar, por lo menos, dos condicionamientos para ello: uno, que no se contemple para todo tipo de delitos (Córdoba, 2003, p. 78); y, otro, que ello no se haga a costa de los derechos y las garantías de los sindicados o procesados en el marco de una concepción garantista, propia de un Estado social y democrático de Derecho (Córdoba, 2003, p. 91). Incluso, otro grupo doctrinario, al examinar la normativa anterior y de cara a los desarrollos jurisprudenciales observados, llegó a afirmar, cuando apenas se discutía el proyecto de Código de Procedimiento Penal, que la víctima ya era tenida como parte del proceso penal por la Corte Constucional (Guerrero, 2004, p. 438).

Para terminar, otro sector de la opinión propende por la exclusión de la víctima del proceso penal pues su participación quiebra el principio de igualdad y entorpece el proceso y su objetivo; en este sentido, se señala que las garantías se originan en una relación de subordinación entre el Estado como gobernante y el procesado como gobernado, por lo cual el sujeto activo de las mismas es quien está al lado opuesto al del Estado en su pretensión de acusar y no quien pretenda lo mismo que él. En consecuencia, y como quiera que el proceso penal está estructurado de manera que el protagonista único sea el sindicado sobre quien recae la decisión, la discusión sobre la imposición de sanciones penales solo puede presentarse entre quienes tienen legitimidad sobre ella o su evitación, es decir, entre el sindicado, por ser su derecho, y el Estado, por estar legitimado para limitarlo. Solo así, se conforma una litis en condiciones de igualdad (Sampedro, 2003, pp. 342-343).

Por lo anterior, la víctima no tiene legitimidad para participar en el proceso penal para limitar la libertad y los demás derechos del sindicado, salvo la persecución de un derecho patrimonial, pues con ello se quebraría el principio de la igualdad. Es más, se afirma que el derecho patrimonial de quien puede llegar a 
ser víctima de un delito debe ser objeto de debate en un proceso civil y no en uno penal (Sampedro, 2003, p. 344; Sampedro, 2003a, pp. 289 y ss.), pues, se itera, la víctima no está legitimada para pretender el objeto de discusión (la responsabilidad penal, la libertad) sino que, al romper la igualdad, entorpece el proceso y el logro de sus objetivos. Para culminar se advierte que, si bien las víctimas tienen un derecho legítimo a tutelar sus intereses económicos, a obtener justicia y a conocer la verdad, ello no implica que deban estar presentes en el proceso penal como sujetos procesales.

Esta última postura no es de extrañar, máxime si en uno de los sistemas que ha servido de espejo al modelo nacional -para el caso el de los Estados Unidos-, la víctima ha sido excluida del sistema federal y su inclusión queda en manos de los respectivos Estados federados; ello es producto de que, como se sabe, el ministerio fiscal tiene allí el monopolio de la acción pública lo cual impide que cualquiera otra parte (sea pública o privada) pueda acusar en el proceso penal a su lado (Gómez, et al, 2013, p. 169; Gómez, 2015, pp. 126 y ss.). No obstante, desde los años setenta del siglo pasado se observa un cambio que, de forma lenta, pero segura, augura nuevos rumbos, por ejemplo, en Estados que, como California, lideran un cambio (pp. 173-174).

\section{Análisis de las diversas posiciones doctrinales y jurisprudenciales}

Pues bien, como ya quedó visto, para algunos autores la participación de la víctima en el proceso penal de manera activa y directa, en igualdad con las otras partes de la actuación, se justifica en la medida en que ella tenga intereses particulares para obtener la verdad, la justicia y la reparación que tiene que defender al interior del proceso penal. Por ello, recuérdese, uno de los autores citados afirma que en el proceso hay tres intereses en juego, "el del Estado como representante de la sociedad, el de la víctima y el del procesado" (Cerón, 2008, p. 205).

Por supuesto, no es cierto que en la persecución y castigo del delito las víctimas tengan un interés particular diverso al del Estado representado por la Fiscalía General de la Nación. Lo anterior, por cuanto es la Constitución Nacional misma la que, en el artículo 250, le impone al ente acusador la obligación de salvaguardar, garantizar y satisfacer los derechos de las víctimas, que, a voces de la Corte Constitucional, se contraen a conocer la verdad, a que se haga justicia y a obtener la reparación, eso sí, "sin que la víctima o el perjudicado puedan desplazar a la Fiscalía o al Juez en el cumplimiento de sus funciones constitucionales, y sin que su participación transforme el proceso penal en un instrumento de retaliación o venganza contra el procesado" (Sentencia C-228, 2002). Luego, entonces, si fuera cierto que la víctima tiene unos intereses particulares diversos a los de la Fiscalía General de la Nación, no tendría ningún sentido que la Constitución Nacional le encomendara al ente acusador la salvaguarda de los derechos del ofendido.

En consecuencia, el Estado, que en la contienda penal está representado por la Fiscalía General de la Nación, no solo representa a la sociedad, sino también a la víctima. De hecho, se puede afirmar, contrario a lo expuesto por los autores atrás 
señalados, que la víctima y la Fiscalía General de la Nación comparten los mismos intereses, pues, en un Estado social y democrático de Derecho como el colombiano, una de las funciones primordiales es la necesidad de alcance y realización de la justicia que surge de los artículos $2^{\circ}, 229$ y 230 de la Carta, y que se traduce en la búsqueda de la verdad como valor, principio y derecho constitucional (Corte Constitucional, sentencia C-396, 2007).

Por ello, la labor de la Fiscalía General de la Nación de investigar y acusar a los presuntos responsables de conductas punibles se encamina a la consecución de los siguientes fines:

(i) la búsqueda de la verdad material sobre la ocurrencia de unos hechos delictivos; (ii) la consecución de la justicia dentro del pleno respeto por la dignidad humana y los derechos fundamentales del procesado; (iii) la protección y reparación integral de los perjuicios ocasionados a las víctimas; (iv) la adopción de medidas efectivas para la conservación de la prueba; y (v) el recurso, dentro del marco estricto de la ley, a mecanismos que flexibilicen la actuación procesal, tales como la negociación anticipada de la pena y la aplicación del principio de oportunidad (Corte Constitucional, sentencia C- 591, 2005).

Así las cosas, la razón para afirmar que la participación de la víctima de manera directa y activa en el proceso penal no vulnera el principio de igualdad de armas, no puede ser que ella tenga un interés particular diverso al de la Fiscalía General de la Nación y de la defensa, pues la fiscalía también propende por la verdad, la justicia y la reparación.

Ahora bien, no es correcto decir, como de manera desacertada lo afirma Gaviria (2015, p. 467), que con la reforma constitucional introducida mediante el Acto Legislativo 03 de 2002 no se haya implantado un sistema procesal penal adversarial, pues, si bien el artículo 250 de la Carta no lo expresa de manera taxativa, basta leer el apartado constitucional para advertir que dentro del articulado se encuentran inmersos los principios propios que caracterizan tal modelo de enjuiciamiento criminal. Así, se introduce la separación de las funciones de investigación y acusación de las de juzgamiento; se incorpora la figura del juez con funciones de control de garantías, encargado de ejercer el control judicial de la limitación de derechos fundamentales; el principio de oportunidad; el juicio está orientado por los principios de oralidad, contradicción, inmediación y publicidad; y, por último, sin que ello signifique que sea menos importante, un procedimiento que reconoce a acusador y acusado la condición de partes iguales.

Adicional a lo expuesto, en la Exposición de Motivos del proyecto de Acto Legislativo 237 de 2002 (Gaceta del Congreso No. 134, 2002), que generó la promulgación del Acto Legislativo 03 de 2002, se consignó que la iniciativa de reforma constitucional tenía como finalidad modificar la estructura del esquema procesal penal mixto, para

[a]doptar uno de clara tendencia acusatoria en donde se conciba el proceso penal como «una contienda entre dos sujetos procesales (defensa y acusador) ubicadas 
en un mismo plano de igualdad, al final del cual, como resultado del debate oral y dinámico, el tercero imparcial que es el juez, tomará una decisión.

Y se puntualizó:

El propósito de esta reforma es fortalecer la función de la Fiscalía General de la Nación y la Defensoría Pública, en la medida en que se reasignarán funciones de acuerdo a como deberán desempeñarse en un sistema acusatorio, en aras de permitir mayor especialidad y eficiencia en las funciones que ejerce cada una, dentro del marco de colaboración y equilibrio, garantizando así a todo ciudadano el acceso a la administración de justicia.

También, en la ponencia para el primer debate de la primera vuelta surtido en la Cámara de Representantes (Gaceta del Congreso No. 148, 2002) se indicó que era necesario modificar el esquema de procesamiento criminal para abandonar el sistema mixto y adoptar un sistema de clara tendencia acusatoria, caracterizado por la creación de un juicio oral, público, contradictorio y concentrado, en el cual "dos sujetos en plano de igualdad (acusador y defensa) debatirán sus argumentos, y un tercero imparcial, que es el juez, decidirá sobre la responsabilidad o no del acusado, fundado en el debate previo entre fiscal y defensa", lo cual fue reiterado en la ponencia del segundo debate de la primera vuelta en el Senado de la República (Gaceta del Congreso No. 232, 2002).

Y, para culminar, en el Informe de ponencia para el primer debate de la segunda vuelta ante el Senado de la República (Gaceta del Congreso No. 531, 2002), se señaló:

El sistema que se propone (a) La etapa de investigación. (...) Las víctimas serán atendidas de manera integral. Ejercerán sus derechos y harán sus solicitudes a través de la Fiscalía, y la ley decidirá si podrán ejercer la vocería en la audiencia pública. Se respetarán sus derechos a la información y a la reparación integral.

Así las cosas, es indiscutible que se implantó un sistema de procesamiento criminal adversarial caracterizado, a grandes rasgos, por la separación de las funciones de investigación y acusación de las de juzgamiento, el control judicial de la limitación de derechos fundamentales por parte del juez de control de garantías, el principio de oportunidad, el juicio orientado por los principios de oralidad, la contradicción, la inmediación y la publicidad; y, añádase, con igualdad de armas, razón por la cual la víctima ejercería sus derechos a través de la Fiscalía General de la Nación.

Ahora bien, algún sector de los estudiosos asegura que la discusión sobre la participación de la víctima en el proceso penal no debe plantearse como un problema derivado del derecho a la igualdad; sin embargo, un autor, al hacer un análisis de la jurisprudencia constitucional, encuentra incomprensible que a la víctima no se le permita exponer su teoría del caso al inicio del juicio oral, pero sí se encuentre facultada para desarrollarla sin exponerla, pues ello "coloca en desventaja a la defensa dentro del juicio oral, porque la obliga a ejercer su labor sin conocer previamente cual [sic] es la teoría del caso que -muy seguramente con tendencia 
acusatoria- utilizará la víctima en desarrollo de su intervención" (Reyes, 2007, p. 89). Más adelante, afirma que, según la jurisprudencia, la víctima no tiene la obligación de descubrir los elementos materiales probatorios y evidencia física con la que cuenta en la audiencia de formulación de acusación "con lo cual se genera un desequilibrio frente a la defensa, que solo puede conocer las pruebas de la víctima durante la audiencia preparatoria [...]" (Reyes, 2007, p. 93).

Surge aquí la contradicción del autor, pues si bien afirma que la intervención de la víctima de manera directa en el proceso penal no genera desigualdad de armas, luego, al analizar algunas facultades concretas reconocidas por la Corte Constitucional, admite que con ellas se genera un "desequilibrio" o "desventaja", lo cual se traduce en una indiscutida vulneración del principio de igualdad de armas, pues con él se garantiza que las partes se enfrenten ante un tercero imparcial, que es el juez, con las mismas herramientas y posibilidades, sin privilegios ni desventajas.

En conclusión, contrario a lo manifestado por este último expositor, la participación de la víctima de manera directa y activa en el proceso penal, tal y como está concebida, no es un problema de legitimidad, como que el legislador le impuso a la Fiscalía General de la Nación -y solo a ella- la obligación de investigar y acusar a los presuntos responsables de la comisión de delitos, salvo, claro está, los eventos en los que va a proceder la acusación privada; sino que dichas prerrogativas se erigen como una evidente transgresión del principio de igualdad de armas, pues, su participación activa, en algunos casos genera un desequilibrio entre las partes, generalmente en disfavor del acusado.

En fin, debe decirse que es muy extrema la postura asumida por Sampedro (2003, p. 342; 2003a, pp. 289 y ss.), para quien la víctima debe ser excluida del proceso penal, pues no tiene legitimidad para pretender la limitación de la libertad y otros derechos del sindicado, amparándose en la persecución de un derecho patrimonial, pues, con ello, se quebraría el principio de la igualdad. Esto, por cuanto, en primer lugar, es innegable que la víctima persigue, además de un interés económico o patrimonial, la verdad, la justicia y, en consecuencia, busca acceder a la administración de justicia. En segundo lugar, porque no es cierto que el objeto del proceso penal sea, en estricto sentido, limitar la libertad del imputado, pues hay casos en los cuales no se produce la restricción de la libertad del acusado y, aun así, la víctima encuentra satisfechos sus intereses a la verdad, la justicia y la reparación. Piénsese, por ejemplo, en aquellos eventos en los cuales se puede prescindir de la imposición de la sanción penal cuando ella no resulte necesaria, como sucede en la legislación penal sustantiva (Ley 599 de 2000, art. 34).

En conclusión, pensar hoy en un proceso penal en donde la víctima no tenga participación activa y directa alguna, es ilusorio; sin embargo, también es cierto que la Corte Constitucional sobrepasa los límites que el proceso penal acusatorio impone, concediendo amplias facultades a las víctimas que terminaron por desquiciar la sistemática acusatoria. Negar que, tal y como está concebida, la participación de la víctima en el proceso penal vulnera el principio de igualdad de armas es una falacia. En efecto: la Corte Constitucional señaló que, de conformidad con 
el artículo 371 del Código de Procedimiento Penal, la víctima no puede presentar una teoría del caso de manera autónoma y al margen de la actuación del fiscal "dado el carácter adversarial de esta etapa del juicio penal y la necesidad de proteger la igualdad de armas" (Sentencia C-209, 2007); sin embargo, en atención a lo dispuesto en el artículo 443 de la Ley 906 de 2004, le es permitido, por intermedio de su abogado, presentar alegatos finales al concluir el juicio, participación que "no introduce un desbalance en el juicio ni le resta su dinámica adversarial puesto que ella se presenta al final de esta etapa, con miras precisamente a que la voz de las víctimas se escuche antes de concluir esta etapa del proceso" (Sentencia C-209, 2007). No obstante, ella se encuentra imposibilitada para presentar replica en los alegatos de conclusión porque, se dice, permitírselo generaría un "desbalance desproporcionado de la posición del acusado" (Sentencia C-616, 2014).

Así las cosas, la postura asumida por la Corte Constitucional, además de contradictoria, vulnera el principio de igualdad de armas. Es cierto que la víctima no puede, de manera autónoma y al margen de la actuación del fiscal, presentar una teoría del caso, pues, en un sistema adversarial, el acusador es, en esencia y de forma exclusiva, la Fiscalía General de la Nación. Bajo ese entendido, solo a esta última le corresponde presentar una teoría del caso, por cuanto ella es la llamada a demostrar que el delito existió y que el acusado es su responsable, es decir, es al acusador a quien le corresponde desvirtuar la presunción de inocencia que cobija al acusado, carga que no tiene la defensa en virtud del principio constitucional que hace presumirla (Corte Constitucional, sentencia C-069, 2009).

Ahora bien, la declaración inicial o el alegato de apertura (Baytelman y Duce, 2004, pp. 90 y ss.) se constituye en la primera oportunidad para que tanto la fiscalía como la defensa expongan ante el juez cuál va a ser su posición con miras a demostrar la responsabilidad o inocencia del acusado, de acuerdo con los elementos fácticos, jurídicos y probatorios acopiados y habrán de presentarse y valorarse en el debate probatorio; en consecuencia, la teoría del caso demarca el objeto del debate, que concluye con la presentación de los alegatos finales, de conclusión o clausura, "los cuales se constituyen en uno de los momentos esenciales del debate adversarial, pues concentran la discusión y el debate jurídico entre la acusación y la defensa" (Sentencia C-616, 2014); luego, entonces, existe una relación inescindible entre los alegatos de apertura -o teoría del caso-, el debate probatorio y los alegatos de clausura.

En consecuencia, si, como lo afirma la Corte Constitucional, los alegatos de conclusión concentran la discusión y el debate jurídico entre la acusación y la defensa, resulta contrario al principio de igualdad de armas que, a la víctima, la cual no presentó alegatos de apertura y no intervino en el debate oral -pues, a voces de la misma corporación, de permitírselo se vulneraría el principio de igualdad de armas- se le permita clausurar una contienda en la que no participó. La Corte justifica su postura con el argumento de que "la voz de las víctimas se escuche antes de concluir esta etapa del proceso" (Sentencia C-209, 2007), posición inadmisible, pues, si se es coherente, debe decirse que, en la audiencia de juicio oral, cuya con- 
clusión es el anuncio del sentido del fallo de conformidad con lo establecido en el artículo 445 de la Ley 906 de 2004, la voz de las víctimas es oída por intermedio del representante de la Fiscalía General de la Nación, en quien recae el mandato constitucional de velar por sus interés en esa etapa del proceso, según la misma jurisprudencia.

Ahora bien, recuérdese que la Corte Constitucional declaró exequible el artículo 357 de la Ley 906 de 2004 en el entendido que las víctimas pueden realizar solicitudes probatorias en la audiencia preparatoria por intermedio de su apoderado, luego de considerar que "la efectividad del derecho a acceder a la justicia, en el que se inscriben los derechos a la verdad, a la justicia y a la reparación de las víctimas, se encuentra en una relación directa con el derecho a probar" (Sentencia C-454, 2006), por lo cual resulta obligatorio concederle dicha prerrogativa que, de modo alguno, confronta las características del sistema procesal penal, en tanto las competencias otorgadas a la Fiscalía General de la Nación en el artículo 250 de la Carta "no tienen la virtualidad de desplazar a la víctima, cuando en un ejercicio soberano de su derecho de acceso a la justicia, opta por agenciar por su cuenta (a través de su representante) sus intereses dentro del proceso penal" (Sentencia C-454, 2006).

Sin embargo, la misma corporación señaló que la víctima no puede participar en su práctica mediante el interrogatorio al testigo ni oponiéndose a las preguntas formuladas en el juicio oral, porque "el ejercicio de las aludidas facultades probatorias tiene lugar durante la etapa del juicio oral y, en ella -como se apuntó-, la participación directa de la víctima trastocaría el sistema penal, afectaría la igualdad de armas y convertiría a la víctima en segundo acusador" (Sentencia C-343, 2007); ello significa, entonces, que la víctima puede solicitar pruebas, pero no puede intervenir en su práctica, so pena de vulnerar el principio de igualdad de armas.

Pues bien, no es cierto que la satisfacción de los derechos de las víctimas a la verdad, la justicia y la reparación, se encuentre vinculada de forma inescindible con el derecho a probar; como que la víctima solo puede ver cumplidas sus garantías constitucionales si se le permite solicitar pruebas en la audiencia preparatoria. Razonar de esa manera sería como decir que solo con la intervención de ella, en forma directa y activa en la audiencia preparatoria, se satisfacen dichos intereses, lo cual no es cierto, pues, se itera, la labor de la Fiscalía General de la Nación de investigar y acusar a los presuntos responsables de conductas punibles también se encamina hacia la consecución de la verdad, la justicia y la reparación (Corte Constitucional, sentencia C-591, 2005). Adicional a lo expuesto, debe recordarse que, en un sistema penal acusatorio, es al acusador a quien le corresponde probar que el delito existió y que el acusado es su responsable; luego, entonces, permitirle a la víctima que solicite pruebas en forma directa en la audiencia preparatoria dirigidas a demostrar la existencia del hecho y la responsabilidad del acusado, sería tanto como otorgarle una facultad inherente a la labor del acusador, convirtiéndose ella, además, en un contendor adicional, lo cual vulnera, a todas luces, el principio adversarial y, de contera, el principio de igualdad de armas. 
Tampoco es atinada la posición de la Corte según la cual el cumplimiento de las funciones que la Constitución Nacional le impone a la Fiscalía General de la Nación no desplazan la intervención de la víctima, quien puede "agenciar por su cuenta (a través de su representante) sus intereses dentro del proceso penal", pues ello significaría, ni más ni menos, que ella pasaría de ser un interviniente especial a convertirse en una parte, con las mismas facultades del acusador y del acusado, con la consiguiente desnaturalización del sistema procesal de adversarios. Esta posición, coincide con la expuesta de forma reiterada por la Sala de Casación Penal de la Corte Suprema de Justicia, para la cual las solicitudes probatorias de la víctima deben ser canalizadas por medio de la Fiscalía, pues este es el único interlocutor válido que puede allegarlas y controvertirlas en el debate oral, como quiera que la práctica de pruebas corresponde, de manera exclusiva y excluyente, a las partes, esto es, a la Fiscalía y a la defensa; pruebas que deben ser descubiertas por el acusador en la audiencia de formulación de acusación (Corte Suprema de Justicia, sentencia radicado 37596, 2011 y Auto 45667, 2015). Considera, pues, la Corte Suprema de Justicia que permitirles a terceros ajenos a los dos adversarios -que, entre otras cosas, postulen teorías del caso, descubran, enuncien, soliciten y participen en la práctica y formación de pruebas- anularía la igualdad de los dos contrarios y "no habría lugar a aplicar las reglas de un proceso como es debido" (Sentencia radicado 37596, 2011), tesis que ha sido controvertida por la doctrina (Gaviria, 2012, pp. 13 y ss.).

Ahora bien, la Corte Constitucional declaró exequible condicionalmente el numeral $2^{\circ}$ del artículo 284 del Código de Procedimiento Penal, en el entendido de que la víctima también puede solicitar la práctica de pruebas anticipadas ante el juez con funciones de control de garantías (Corte Constitucional, sentencia C-209, 2007). Dijo esa Corporación que, en tratándose de las facultades probatorias de las víctimas, la etapa procesal es determinante para establecer si pueden ser ejercidas de forma directa por ella (o su apoderado) o si, en consideración a los rasgos estructurales y características esenciales del sistema penal con tendencia acusatoria diseñado por el legislador en la Ley 906 de 2004, dicha facultad debe ser ejercida de manera indirecta a través del fiscal. Entonces, como la práctica de pruebas anticipadas se lleva a cabo en una etapa anterior al juicio ante el juez con funciones de control de garantías, otorgarle esta facultad probatoria a la víctima no modifica los rasgos estructurales del proceso, no altera la igualdad de armas ni modifica la calidad de víctima como interviniente especial.

Debe recordarse que, en virtud del diseño procesal acusatorio asumido, las pruebas solo se practican en el juicio ante el juez de conocimiento, con inmediación; sin embargo, dicha regla general tiene su excepción, cual es, recuérdese, la práctica de 'pruebas' anticipadas ante el juez con funciones de control de garantías por motivos fundados y de extrema necesidad y para evitar la pérdida o alteración del medio probatorio; las mismas se practican "en audiencia pública y con observancia de las reglas previstas para la práctica de pruebas en el juicio", lo que garantiza el respeto de los principios constitucionales de legalidad, publicidad y contradicción establecidos en el artículo 29 de la Constitución Nacional (Corte Constitucional, sentencia C-591, 2005). Así las cosas, aunque las pruebas 
se practiquen en una audiencia preliminar ante el juez con funciones de control de garantías, ello debe surtirse en una audiencia pública con la observancia de las formas previstas a tales efectos en el juicio oral, anticipándose solo por extrema necesidad y para evitar la pérdida o la alteración del medio probatorio. Así, si la víctima no puede intervenir en la práctica de pruebas en el juicio oral ante el juez de conocimiento, pues ello resultaría violatorio al principio de igualdad de armas -por la misma razón, tampoco debería permitírsele solicitar la práctica de pruebas anticipadas-, en atención a que ello implica, indefectiblemente, una modificación de los rasgos estructurales del sistema penal acusatorio. En conclusión, con independencia del momento procesal en que se practica la prueba -en una audiencia preliminar ante el juez con funciones de control de garantías o en la audiencia del juicio oral ante el juez de conocimiento-, permitirle a la víctima participar en el debate probatorio la convierte en un segundo acusador o contradictor, con la indiscutible vulneración del principio de igualdad de armas que, como recuerda la teoría del derecho procesal penal argentina, supone "una relación horizontal y de lucha entre las partes, por un lado, y de subordinación de ambas partes al juzgador neutral, por el otro" (Bovino, 1998, p. 242).

Ahora bien, en la decisión citada se faculta a la víctima para que, en la audiencia de formulación de acusación, solicite el descubrimiento de un elemento material probatorio específico o de evidencia física específica (Ley 906, 2004, Art. 344); y para que, en la audiencia preparatoria, (i) haga observaciones sobre el descubrimiento de elementos probatorios y de la totalidad de las pruebas que se harán valer en la audiencia del juicio oral (Art. 356), (ii) solicite la exhibición de los elementos materiales probatorios y evidencia física con el fin de ser conocidos y estudiados (Art. 358) y, (iii) solicite la exclusión, el rechazo o la inadmisibilidad de los medios de prueba (Art. 359). Estas prerrogativas, en sentir de la Corte, no modifican los rasgos estructurales del proceso ni alteran la igualdad de armas ni modifican la calidad de víctima como interviniente especial, pues, además de que su participación se verifica en una etapa previa al juicio oral, no se le permite participar en la práctica de la prueba ni en su contradicción; sin embargo, al contrario de lo expuesto por ese organismo judicial, la participación de la víctima en el descubrimiento probatorio sí vulnera el principio de igualdad de armas, en cuanto, si bien el juicio oral es el centro del sistema sometido a los principios de oralidad, inmediación, contradicción y publicidad, ello no significa que los actos encaminados a preparar el juicio escapen del sistema adversarial, entre ellos, el ofrecimiento probatorio o Discovery (Gómez, 2008, pp. 30-31).

En efecto, el descubrimiento probatorio "es un medio de equilibrio entre las partes para un correcto ejercicio del contradictorio y obviamente del derecho a la defensa" (Guerrero, 2005, p. 292) que consiste, a voces de la Corte Suprema de Justicia, en que los adversarios, es decir, el acusador y el acusado, "suministren, exhiban o pongan a disposición de la contraparte todas las evidencias y elementos probatorios de que dispongan"; y, añade, "anuncien todas las pruebas cuya práctica solicitarán para ser llevadas a cabo en el juicio oral, para respaldar su teoría del caso" (Sentencias radicado 25920, 2007; radicado 31614, 2009); por tal razón, se 
relaciona en forma directa con el principio de igualdad de armas entre los contendores. Es decir, el descubrimiento probatorio está previsto de manera exclusiva para las dos partes opuestas -acusador y acusado- y les garantiza que la contienda se va a surtir en igualdad de armas, de forma que, permitirle a la víctima participar en esta fase del proceso generaría un resquebrajamiento del sistema de enjuiciamiento criminal, concretado a partir del debate realizado por dos contrarios frente a un juzgador imparcial, lo que impide la participación de un tercero.

Por ello, la Corte Constitucional señaló que el descubrimiento probatorio es una manifestación concreta del principio de igualdad de armas que tiene como propósito que cada parte -acusador y acusado-, conozca el material de convicción que su contradictor hará efectivo en el juicio oral, evitando la presentación sorpresiva de elementos de convicción, lo cual comprometería de manera grave los derechos de defensa y contradicción (Corte Constitucional, sentencia C-1194, 2005). Postura que coincide con la expuesta por un sector de la doctrina, para el cual el descubrimiento probatorio pretende garantizar la trasparencia del juicio penal, pues, aunque él está cimentado sobre las bases de una contienda, el fin último del proceso "es la realización de la justicia material, lo cual implica que el discurso sobre la responsabilidad penal del acusado debe erigirse sobre la base de hechos conocidos y dudas razonables, pero no de pruebas ocultas o acusaciones inesperadas" (Guerrero, 2005, p. 282).

En la misma decisión, se facultó a la víctima para solicitar medidas de aseguramiento (Ley 906 de 2004, Art. 306), su modificación cuando el imputado ha incumplido las obligaciones impuestas al concederle la detención domiciliaria (Art. 316) y medidas de protección (Art. 342); tales facultades, en el sentir de la Corte Constitucional, se proyectan en la protección de los derechos de las víctimas ante la omisión del fiscal en el cumplimiento de su deber o ante circunstancias imperiosas frente a las cuales la víctima cuente con información privilegiada "[s]obre hostigamientos o amenazas recibidas que hagan necesaria la imposición de la medida correspondiente, o sobre el incumplimiento de la medida impuesta, o la necesidad de cambiar la medida otorgada" (Sentencia C-209, 2007), prerrogativa que no genera una desigualdad de armas, sino que asegura la adecuada protección de los derechos constitucionales del ofendido.

Pues bien, permitir que la víctima solicite la imposición de una medida cautelar personal contraría el principio de igualdad de armas, pues el ofendido no puede usurpar competencias que constitucionalmente le vienen otorgadas a la Fiscalía General de la Nación. En este punto, debe, de nuevo, recordarse el contenido claro y expreso del artículo 250 de la Carta, en sus numerales 1, 6 y 7. Luego, entonces, quien se encuentra facultado por la Constitución Nacional para solicitar este tipo de medidas es, exclusivamente, la Fiscalía General de la Nación, y la omisión en el cumplimiento de su deber no puede ser razón suficiente para modificar la competencia constitucional.

Adicional a lo expuesto, si se faculta a la víctima para reivindicar la protección de sus derechos cuando "cuente con información de primera mano sobre hostiga- 
mientos o amenazas recibidas que hagan necesaria la imposición de la medida correspondiente" (Sentencia C-209, 2007), debería permitírsele a cualquier miembro de la sociedad que, cuando cuenta con datos similares acerca de que el imputado puede poner en peligro a la comunidad, por ejemplo, continuando con la comisión de delitos, solicite en forma directa la imposición de una medida de aseguramiento, para reivindicar la protección de sus garantías, lo cual resulta inadmisible, salvo que en el marco de la acción penal privada se le otorgara esa potestad.

Para culminar, la Corte Constitucional autorizó a la víctima para que, en la audiencia preparatoria, solicite al juez de conocimiento el decreto de la conexidad procesal (Ley 906, 2004, Art. 51), luego de considerar que con dicho instituto -por medio del cual se evita la multiplicidad de actuaciones penales por el mismo comportamiento o por varios delitos en relación de conexidad-se contribuye, entre otros, a la realización de los derechos de las víctimas "al hacer posible que en único trámite puedan formular sus pretensiones de verdad, reparación y justicia" (Sentencia C-471 de 2016). Desde luego, lo más relevante de esta decisión es que creó una regla interpretativa según la cual se "impone la precedencia prima facie del derecho de las víctimas a participar en el proceso penal en iguales condiciones que los otros participantes" (Sentencia C-471, 2016), a menos que su cumplimiento: (a) se oponga a una prohibición constitucional expresa; (b) desconozca competencias, facultades o derechos exclusivos de los otros sujetos que participan en el proceso; o (c) resulte incompatible con la estructura constitucional del proceso penal. Esto último tiene ocurrencia cuando se produce, "(c.1) la modificación de los rasgos estructurales del sistema penal con tendencia acusatoria, (c.2) la alteración de la igualdad de armas, o (c.3) la variación de la calidad de la víctima como interviniente especialmente protegido" (Sentencia C-471, 2016); sin embargo, se afirma que, para determinar la incompatibilidad con la estructura del proceso penal se deberá considerar tanto la etapa procesal de la que se trata y el tipo de intervención debatida, como el grado de interferencia que puede tener en las funciones o facultades de los otros sujetos procesales.

Este pronunciamiento es desatinado por las siguientes razones: en primer lugar, en un sistema penal acusatorio como el vigente resulta inadmisible la inclusión de una cláusula general que implique la participación de la víctima de manera directa y activa en el proceso penal en iguales condiciones que los otros participantes, pues ello implica que la víctima deje de ser un interviniente para convertirse en una parte, en un participante más de la contienda, lo cual resulta contrario a la naturaleza de un sistema de enjuiciamiento acusatorio. En este punto debe recordarse que ni la Constitución Nacional ni la ley le otorgaron a la víctima la condición de parte, sino de interviniente especial, por lo que no debe ni puede tener las mismas facultades del acusado ni del acusador. Entonces, si según la Corte Constitucional la regla general es que la víctima puede participar de manera activa y directa en la contienda, se está frente a un sistema de enjuiciamiento cualquiera que sea, excepto acusatorio.

En segundo lugar, se equivoca la Corte Constitucional cuando afirma que, para determinar si la participación de la víctima resulta incompatible con la estructura constitucional del proceso penal, se debe considerar la etapa procesal de la que 
se trata. Este es un error mayúsculo que, de manera sistemática, repite la Corporación, pues siempre que analiza las facultades de la víctima para intervenir de manera activa y directa en el proceso penal lo hace de cara a la etapa procesal correspondiente, para considerar que puede intervenir en todas las fases del proceso, excepto en algunos momentos del juicio -a ella se le permite alegar de conclusión en esa etapa del proceso-, pues entiende que el principio acusatorio es exclusivo de este último por lo cual se le permite: a) solicitar la práctica de pruebas anticipadas, porque se llevan a cabo antes del juicio oral, aun cuando se trata de una anticipación excepcional del juicio; b) solicitar pruebas, porque ello tiene ocurrencia antes de la iniciación del juicio oral, pero que no pueda practicarlas en la medida en que ello ocurre en esa etapa del proceso. Además, c) participar en el descubrimiento probatorio, pues ello acontece en etapas anteriores al juicio, aun cuando el descubrimiento probatorio es una característica esencial de un sistema acusatorio y se constituye en una garantía de las partes, que lo son, esencial y de forma exclusiva, el acusador y el acusado; d) presentar alegatos de conclusión clausurando un debate en el que no participó; y, e), solicitar medidas de aseguramiento y su modificación porque ello acontece antes del juicio oral, aun cuando, según la Constitución Nacional, esa competencia esta atribuida a la Fiscalía General de la Nación.

Por lo anterior, contrario a lo manifestado por la Corte Constitucional, el principio acusatorio es una característica de todo el sistema de enjuiciamiento penal que se revela en cada una de las fases que lo componen y no del juicio de manera exclusiva. Nótese que figuras propias de un sistema acusatorio como el plasmado en la ley, tienen ocurrencia por fuera de la etapa del juicio oral, incluso prescindiendo de él; ello ocurre, por ejemplo, en las terminaciones anticipadas del proceso penal con ocasión de la aplicación del principio de oportunidad, la preclusión de la investigación, los mal llamados preacuerdos y las negociaciones, la suspensión del procedimiento a prueba, el descubrimiento probatorio, etc. De tal forma, no es cierto que lo acusatorio se predica solo del juicio oral sino de todo el proceso, lo cual significa que en el curso de toda la actuación se debe garantizar, entre otros, el principio de igualdad de armas, motivo por el cual la etapa procesal de la que se trate no puede ser determinante para establecer si la intervención de la víctima de manera directa y activa en el proceso penal es incompatible con la estructura constitucional del proceso penal.

Como se ve, los esfuerzos de la Corte Constitucional de cara a ponderar los derechos de las víctimas a participar de manera activa y directa en el proceso penal y el principio de igualdad de armas, propio de un sistema penal acusatorio, fueron equívocos, pues terminaron por generar el efecto contrario, esto es, vulnerar el principio de igualdad de armas, inclinar la balanza en disfavor del acusado; sin embargo, la solución no está en restarle a la víctima toda participación activa y directa en el proceso penal, sino en encontrar el punto medio en donde la balanza no se incline a favor de uno y en disfavor de otro.

Para tales fines, el análisis de la participación de la víctima en las diferentes etapas del proceso penal debe hacerse de cara a la satisfacción de sus intereses a la verdad, la justicia y la reparación; todo ello de la mano de un verdadero test de ponderación 
o de proporcionalidad, pues se debe determinar cómo solucionar la colisión entre dos tipos de principios (Alexy, 1993, pp. 111 y ss.; Corte Constitucional, sentencia C-022, 1996): de un lado, el llamado principio acusatorio del cual forma parte el axioma de igualdad de armas y, del otro, el principio del libre acceso a la administración de justicia penal, que tiene la víctima. Entonces, si con la facultad pretendida no se satisface alguno de estos intereses, la víctima no podrá intervenir de manera activa y directa en el proceso penal. Si, por el contrario, se advierte que su aportación está dirigida a la consecución de uno cualquiera de tales intereses, se deberá permitir su intervención. Eso sí, siempre que no se socaven las bases estructurales del sistema penal acusatorio, para generar una desigualdad de armas para lo cual se deberá analizar la naturaleza del instituto o de la facultad que se pretende.

Planteada así la tesis central de esta incursión académica, a continuación se examinan algunas prerrogativas concedidas a la víctima por intermedio de la jurisprudencia de la Corte Constitucional de cara a la regla esbozada, a fin de establecer si, con su ejercicio, se vulnera o no el principio de igualdad de armas. El análisis debe comenzar por la facultad que tiene la víctima para solicitar la práctica de pruebas, bien de manera anticipada ante el juez con funciones de control de garantías, ora, en la audiencia preparatoria ante el juez con funciones de conocimiento.

Pues bien, como ya quedó visto, el primer nivel de análisis obliga a establecer si existe una relación entre la facultad pretendida y los intereses de la víctima a la verdad, la justicia y la reparación. En efecto, frente a la omisión de la Fiscalía General de la Nación de solicitar la práctica de una prueba fundamental para estructurar su teoría del caso, los intereses de la víctima podrían verse huérfanos de protección, pues, sin la incorporación de evidencia tan fundamental, el resultado del juicio podría ser contrario a los intereses de las víctima a obtener verdad y justicia; piénsese, por ejemplo en un asunto en donde el ente acusador omita solicitar el testimonio del perito que rindió el informe pericial sobre las causas de la muerte del occiso, luego, entonces, existe una relación entre los intereses de la víctima y las facultades aludidas, razón por la cual el primer nivel se encuentra satisfecho.

El segundo nivel de argumentación obliga a establecer si, con el otorgamiento de la facultad exigida, no se socavan las bases estructurales del sistema penal acusatorio y genera una desigualdad de armas, por lo cual se deberá analizar la naturaleza del instituto o de la facultad que se pretende. Pues bien, como quedó visto, en un sistema penal acusatorio, es al acusador a quien le corresponde probar que el delito existió y que el acusado es su responsable, por ende, permitir que la víctima solicite pruebas en cualquier etapa del proceso dirigidas a demostrar la existencia del hecho y la responsabilidad del acusado, sería tanto como otorgarle una facultad inherente del acusador, convirtiéndose ella en un contendor adicional lo que, a todas luces, vulnera el principio adversarial y, de contera, el principio de igualdad de armas.

Adicional a lo expuesto, la omisión de la Fiscalía General de la Nación en el cumplimiento de las funciones que le son inherentes no justifica, de modo alguno, que la víctima pueda desplazarla en el rol que desempeña, ello significa, ni más ni 
menos, que aquella pasaría de ser un interviniente especial a convertirse en una parte con las mismas facultades del acusador y del acusado, con la consiguiente desnaturalización del sistema procesal de adversarios. En conclusión, con independencia del momento procesal en el cual se practica la prueba -bien en una audiencia preliminar ante el juez con funciones de control de garantías o en la audiencia del juicio oral ante el juez de conocimiento-, permitirle a la víctima participar en el debate probatorio la convierte en un segundo acusador o contradictor, con la indiscutible vulneración del principio de igualdad de armas. Por lo anterior, consentir a la víctima que solicite la práctica de pruebas es inconstitucional, pues cambiaría la naturaleza misma de la Constitución en la cual se dispone un sistema procesal penal acusatorio, caracterizado por el principio de igualdad de armas.

Para seguir con el estudio de algunas facultades que la Corte Constitucional le reconoce a la víctima, debe ahora hacerse referencia a la posibilidad de participar en el descubrimiento probatorio, bien en la audiencia de formulación de acusación, ora, en la audiencia preparatoria. Adentrándose en el examen del primer nivel de análisis, que obliga a establecer si existe una relación entre la facultad pretendida y los intereses de la víctima a la verdad, la justicia y la reparación, se tiene que, en primer lugar, podría existir una relación directa o indirecta entre tales prerrogativas y los interés de la víctima a obtener esos derechos en aquellos casos en los cuales la Fiscalía incumpla con el rol que constitucionalmente le viene signado; por ejemplo, en un asunto en el cual el ente acusador no solicite la exclusión de una prueba ilícita, o la inadmisión de una prueba impertinente o inútil, etc., encontrándose así satisfecho el primero de los requisitos.

Ahora bien, según el planteo asumido, corresponde examinar la naturaleza del instituto o de la facultad que se pretende ejercer, que en este caso lo es, participar en el descubrimiento probatorio, a fin de establecer si, con la intervención de la víctima en esa actividad procesal, se vulnera el principio de igualdad de armas, es decir, si con su intervención se inclina o no la balanza en favor de una parte y en disfavor de la otra. Como ya se indicó, el descubrimiento probatorio es una manifestación concreta del principio de igualdad de armas, que tiene como propósito que cada parte -acusador y acusado- conozca el material de convicción que su contradictor hará efectivo en el juicio oral, evitando la presentación sorpresiva de elementos de convicción, lo que comprometería gravemente los derechos de defensa y contradicción. Entonces, en un sistema penal acusatorio, el descubrimiento probatorio está previsto de manera exclusiva para las dos partes opuestas -acusador y acusado- y les garantiza que la contienda se va a surtir en igualdad de armas.

Por ello, permitirle a la víctima que participe en esta fase del proceso genera un resquebrajamiento del sistema de enjuiciamiento criminal, concretado a partir del debate realizado por dos contrarios frente a un juzgador imparcial, de donde se desprende la imposibilidad de autorizar la participación de un tercero, lo cual resulta inadmisible. Por lo anterior, aprobar que la víctima participe en el descubrimiento probatorio es inconstitucional, dado que cambia la naturaleza misma de la Constitución, cuando establece un sistema procesal penal acusatorio caracterizado por el principio de igualdad de armas. 
Contrario sensu, no contrarían la Constitución Nacional la posibilidad de que la víctima controvierta la sentencia absolutoria (Art. 176) o la decisión que se emite como consecuencia de acuerdos realizados entre el imputado y la Fiscalía General de la Nación (Art. 35. Inc. $5^{\circ}, 446$ y 447), aquella como producto de una solicitud de preclusión por parte del fiscal (Art. 332, 333 y 334); la decisión a través de la cual la fiscalía aplica el principio de oportunidad, una vez sometida al control del juez de control de garantías (Art. 327 y 329); el archivo definitivo de la actuación por la aplicación de la suspensión del procedimiento a prueba (Arts. 325, 326 y 327) e, incluso, la orden de archivo de las diligencias (Art. 49).

Acorde con el examen del primer nivel de análisis, resulta evidente que existe una relación directa entre tales prorrogativas y la satisfacción de los intereses de la víctima a la verdad, la justicia y la reparación; lo que se hace más evidente cuando se trata de las distintas formas de terminación anticipada del proceso, en donde, posiblemente, podría existir una confrontación entre los intereses de las víctimas y los de la Fiscalía General de la Nación. Adicional a esto, el ejercicio de tales prerrogativas no implica un resquebrajamiento de las bases estructurales del sistema penal acusatorio, ni genera un desbalance en la contienda, y, por lo tanto, no genera una violación al principio de igualdad de armas como quiera que en tales fases la contienda ya ha finalizado.

\section{Conclusiones}

Así las cosas, en un contexto en el cual se observa la irrupción de la víctima en el derecho penal (Bustos y Larrauri, 1993, pp. 9 y ss., 43 y ss.), al punto de que se habla de un 'renacimiento' de la misma (Eser, 1992, pp. 13 y ss.), después de mirar si su marcada injerencia en el proceso penal colombiano desborda el postulado de la igualdad de armas, llegados a esta instancia del análisis, debe decirse lo siguiente:

A partir del Acto Legislativo 03 de 2002, por medio del cual se modificaron los artículos 116, 250 y 251 de la Constitución Nacional, y con la consecuencial promulgación de la Ley 906 de 2004, se implantó en el ordenamiento procesal un sistema penal acusatorio, razón por la cual el legislador le concedió a la víctima escasos escenarios de participación encomendándole a la Fiscalía General de la Nación la defensa de sus intereses.

Así mismo, como ya se dijo, el órgano encargado del control de constitucionalidad en plan de ser coherente con sus decisiones, y para asegurar la protección efectiva de los derechos constitucionales de la víctima a la verdad, la justicia y la reparación, le otorgó ciertos derechos y facultades que le permiten una participación activa y directa en el proceso penal; de esta manera, se generó un desbalance en la contienda a favor del ofendido y en disfavor del acusado, lo cual vulnera el principio de igualdad de armas.

Una de las razones por las cuales la Corte Constitucional erró al momento de ponderar los derechos de las víctimas y el principio de igualdad de armas fue, justo es decirlo, atender a la etapa procesal de la que se tratare, entendiendo que la víctima puede intervenir de forma directa en todas las fases del proceso, excepto 
en algunos momentos del juicio, pues estima que el principio acusatorio es exclusivo de este último cuando, como ya quedó evidenciado, se trata de una característica de todo el sistema de enjuiciamiento penal que irradia cada una de las fases que lo componen, y no solo del juicio. Por ese motivo, la etapa procesal no puede ser determinante para establecer si la intervención de la víctima, de manera directa y activa en el proceso penal, es incompatible con la estructura constitucional del proceso penal.

Así las cosas, este trabajo propone una regla aplicable a todos los eventos en donde se pretenda otorgarle a la víctima la posibilidad de intervenir de manera activa y directa en el proceso penal, en virtud de la cual se pueda encontrar el punto medio en donde la balanza no se incline a favor de uno y en disfavor de otro; todo ello, de la mano de un verdadero test de proporcionalidad o de ponderación, con el cual se busca resolver el conflicto entre los dos principios en juego: el libre acceso a la administración de justicia penal y la igualdad de armas como expresión del postulado más general, denominado principio acusatorio.

\section{Referencias}

Abramovich, V. (2007). El acceso a la justicia como garantía de los derechos económicos, sociales y culturales. Estudio de los estándares fijados por el sistema interamericano de derechos humanos. Washington: Organización de los Estados AmericanosComisión Interamericana de Derechos Humanos. Recuperado de http:/ / www. cidh.org/pdf\%20files/ACCESO\%20A\%20LA\%20JUSTICIA\%20DESC.pdf

Acto Legislativo 03 (2002, diciembre 19). Por el cual se reforma la Constitución Nacional. Diario Oficial No. 45.040, Congreso de la República de Colombia.

Alexy, R. (1993). Teoría de los Derechos Fundamentales (Trad. E. Garzón-Valdés). Madrid: Centro de Estudios Constitucionales.

Ambos, K. (2005). Principios del proceso penal europeo. Análisis de la Convención Europea de Derechos Humanos. Bogotá: Universidad Externado de Colombia.

Auto 39449 (2013, diciembre 11). Casación. M. P. Eyder Patiño Cabrera. Sala de Casación Penal, Corte Suprema de Justicia.

Auto 45667 (2015, mayo 20). Casación. M. P. María del Rosario González Muñoz. Sala de Casación Penal, Corte Suprema de Justicia.

Baumann, J. (1986). Derecho Procesal Penal. Conceptos fundamentales y principios procesales (Trad. C. A. Finzi). Buenos Aires: Depalma.

Baytelman, A., y Duce, M. (2004). Litigación Penal: Juicio Oral y Prueba. Santiago: Universidad Diego Portales.

Bernal, J. y Montealegre, E. (2013). El proceso penal. Fundamentos Constitucionales y Teoría General (tomo I, 6 ed.) Bogotá: Universidad Externado de Colombia. 
Bovino, A. (1998). Problemas del derecho procesal penal contemporáneo. Buenos Aires: Editores del Puerto.

Bustos, J. y Larrauri, E. (1993). Victimología: presente y futuro (hacia un sistema penal de alternativas). Barcelona: PPU.

Caso Sorrentino vs. United States (1947, septiembre 4). 163F.2d 627. U.S. Supreme Court. Recuperado de http:/ /law.justia.com/cases/federal/appellate-courts / F2/163/627/1498351/

Caso United States vs. Conforti (1953, enero 13). 200F.2d 365. U.S. Supreme Court. Recuperado de https: / / casetext.com/case/united-states-v-conforti-3

Caso Portomene vs. United States (1955, abril 27). 221F.2d 582. U.S. Supreme Court. http:/ / openjurist.org/221/f2d/582/portomene-v-united-states

Caso Roviaro vs. United States (1957, marzo 25). 353 U.S. 53. U.S. Supreme Court. Recuperado de http:/ / caselaw.findlaw.com/us-supreme-court/353/53.html

Caso Brady vs. Maryland (1963, mayo 13). 373 U.S. 83. U.S. Supreme Court. Recuperado de https://supreme.justia.com/cases/federal/us/373/83/case. html

Caso Giglio vs. United States (1972, febrero 24). 405 U.S. 150. U.S. Supreme Court. Recuperado de https://supreme.justia.com/cases/federal/us/405/150/case. html

Caso United States vs. Agurs (1976, junio 24). 427 U.S. 97. U.S. Supreme Court. Recuperado de https://supreme.justia.com/cases/federal/us/427/97/case. html

Caso United States vs. Bagley (1985, julio 2). 473 U.S. 667. U.S. Supreme Court. Recuperado de https://supreme.justia.com/cases/federal/us/473/667/case. html

Caso Kyles vs. Whitley (1995, abril 19). 514 U.S. 419. U.S. Supreme Court. Recuperado de https:/ / supreme.justia.com/cases/federal/us/514/419/

Caso Ofner and Hopfinger vs. Austria (1963, abril 5). Tribunal Europeo de Derechos Humanos.

Caso Neumeister vs. Austria (1968, junio 27). Application No. 1936/63. Tribunal Europeo de Derechos Humanos. Recuperado de http://freecases.eu/Doc/ CourtAct/4551732

Caso Delcourt vs. Belgica (1970, enero 17). Application No. 2689/65. Tribunal Europeo de Derechos Humanos. Recuperado de http:/ /hudoc.echr.coe.int/

Caso Brandstetter vs. Austria (1991, agosto 28). Application No. 11170/84; 12876/87; 13468/87. Tribunal Europeo de Derechos Humanos. Recuperado de http:/ /hudoc.echr.coe.int/ 
Caso Bulut vs. Austria (1996, febrero 22). Application No. 17358/90. Tribunal Europeo de Derechos Humanos. Recuperado de http:/ /hudoc.echr.coe.int/

Caso Fischer vs. Austria (2002, enero 17). Application No. 33382/96. Tribunal Europeo de Derechos Humanos. Recuperado de http:/ /hudoc.echr.coe.int/

Caso Lanz vs. Austria (2002, enero 31). Application No. 24430/94. Tribunal Europeo de Derechos Humanos. Recuperado de http://hudoc.echr.coe.int/

Caso Ócalan vs. Turquía (2005, mayo 12). Application No. 46221/99. Tribunal Europeo de Derechos Humanos. Recuperado de http:/ /hudoc.echr.coe.int/

Cerón, L. E. (2008). La víctima en el proceso penal colombiano. Un análisis constitucional de la Ley 906 de 2004 desde una perspectiva victimológica. Bogotá: Ediciones Doctrina y Ley.

Constitución Política (1991). Congreso de la República de Colombia. Colombia.

Córdoba, M. F. (2003). Protección de la víctima en el nuevo sistema procesal colombiano. Derecho penal y Criminología, 24(74), 75-91.

Chocrón, A. M. (2008). Fundamento constitucional de la protección a las víctimas en el proceso penal español. Boletín Mexicano de Derecho Comparado, XLI(122), 691-715.

Daza, A. (2009). El principio de igualdad de armas en el sistema penal colombiano a partir del Acto Legislativo 03 de 2002. Revista de Derecho Principia Iuris (12), 121-145.

De Vicente, J. (1997). La consideración de la víctima a través de la reparación del daño en el Derecho penal español: posibilidades actuales y perspectivas de futuro. Silva, J. M. (ed.), Política criminal y nuevo Derecho Penal (Libro Homenaje a Claus Roxin) (pp. 173-206). Barcelona: Bosch.

Duce, M. (2014). Algunas reflexiones sobre los derechos de las víctimas en el proceso penal chileno. La víctima en el sistema de justicia penal. Una perspectiva Jurídica y criminológica. Política criminal, 9(18), 739-815.

Eser, A. (1992). Acerca del renacimiento de la víctima en el procedimiento penal. Tendencias nacionales e internacionales. En J. B. Maier (Comp.), De los delitos y de las Victimas (pp. 13-52). Buenos Aires: Ad-Hoc.

Esparza,I.(1994). El principio del debidoproceso. Tesis Doctoral.Castellón:Universidad de Castellón. Recuperado de http:/ / www.tesisenred.net/handle/10803/10427

Fernández, W. (1999). Procedimiento Penal Constitucional: Constitución política y proceso. Derechos fundamentales. Derecho comparado. Doctrina - jurisprudencia.. Bogota: Ediciones Librería del Profesional.

Ferrajoli, L. (2009). Derecho y razón. Teoría del garantismo penal (9 ed.) Madrid: Trotta. 
Gaceta del Congreso No. 134. (2002). Bogotá: Congreso de la República. Recuperado de http://www.imprenta.gov.co/gacetap/gaceta.indice?v_num $=134 \& v_{-}$ anog $=2002$

Gaceta del Congreso No. 148. (2002). Bogotá: Congreso de la República. Recuperado de http://www.imprenta.gov.co/gacetap/gaceta.indice?v_num $=148 \& v_{-}$ $\operatorname{anog}=2002$

Gaceta del Congreso No. 232. (2002). Bogotá: Congreso de la República. Recuperado de http://www.imprenta.gov.co/gacetap/gaceta.indice?v_num $=232 \& v_{-}$ anog $=2002$

Gaceta del Congreso No. 531. (2002). Bogotá: Congreso de la República. Recuperado de http://www.imprenta.gov.co/gacetap/gaceta.indice?v_num $=531 \& v_{-}$ anog=2002

Gaviria, V. E. (2009). Estado actual de los derechos de las víctimas en el proceso penal: evolución (¿involución?) dogmática, jurisprudencial y legislativa. Revista Derecho Penal y Criminología, 30(89), 37-71.

Gaviria, V. E. (2012). Descubrimiento y solicitudes probatoria por parte de la víctima. Revista Derecho Penal y Criminología, XXXIII(94), 13-35.

Gaviria, V. E. (2015). Víctimas, Acción Civil y Sistema Acusatorio. (5 ed.) Bogotá: Universidad Externado de Colombia.

Gimeno, V. (2007). Manual de derecho procesal penal. (2. ed.) Madrid: Colex.

Gómez, J. L. (2008). La reforma estructural del proceso penal y la elección del modelo a seguir, 1-59. Recuperado de https://www.unifr.ch/ddp1/derechopenal/ articulos/a_20080521_92.pdf

Gómez, J. L. (Coord.) (2013). Introducción al proceso penal federal de los Estados Unidos de Norteamérica. Valencia: Tirant lo Blanch.

Gómez, J. L. (2015). Los fundamentos del sistema adversarial de enjuiciamiento criminal. Bogotá: Ediciones Jurídicas Andrés Morales.

Guerrero, Ó. J. (2004). Las víctimas en el contexto del Derecho Procesal penal colombiano (perfiles comparativos). La reforma del proceso penal peruano. Anuario de Derecho Penal 2004 (418-443). Lima: Pontificia Universidad Católica del PerúFondo Editorial/Universidad de Friburgo.

Guerrero, Ó. J. (2005). Fundamentos Teórico Constitucionales del Nuevo Proceso Penal. Bogotá: Ediciones Nueva Jurídica.

Horvitz, M. I. y López, J. (2004). Derecho Procesal Penal Chileno (T. II). Santiago: Editorial Jurídica de Chile.

Ley 599 de 2000. Por la cual se expide el Código Penal. Diario Oficial No. 44097. Congreso de la República de Colombia, julio de 2000. 
Ley 906 de 2004. Por la cual se expide el Código de Procedimiento Penal. Diario Oficial No. 45658. Congreso de la República de Colombia, septiembre de 2004.

Ley 1826 de 2017. Por medio de la cual se establece un procedimiento penal especial abreviado y se regula la figura del acusador privado. Diario Oficial No. 50 114, enero de 2017.

Maier, J. B. (2004). Derecho Procesal Penal. Tomo I, (2. ed., 3 reimpresión). Buenos Aires: Editores del Puerto.

Márquez, A. (2006). Las víctimas en el nuevo sistema procesal acusatorio y su reconocimiento por la Corte Constitucional. Prolegómenos. Derechos y Valores, IX (18), 127-151.

Márquez, A. (2009). Facultades de las víctimas como sujetos procesales en el sistema acusatorio de conformidad con la jurisprudencia de la Corte Constitucional. Prolegómenos. Derechos y Valores, XII(23) 21-33.

Molina, C. M. (2010). La víctima en el proceso penal. (2 ed.) Medellín: Diké-Editorial CES.

Moore, H. (1831). Dictionary of Quotations from Various Authors in Ancient and Modern Languages. London: Printed for Whittaker, Treacher \& co.

Parra, M. V. (2010). La Transformación del Derecho en Colombia: su incidencia en el tratamiento de la víctima en el proceso penal. Bogotá: Universidad Externado de Colombia.

Pataki and Dunshirn vs. Austria. (1963, marzo 28). Report. No. 31/63. Comisión Europea de Derechos Humanos.

Proyecto de Acto Legislativo 237 de 2002. Congreso de la República de Colombia, abril de 2002.

Reyes, Y. (2007). La acción civil derivada de la comisión de un delito y el sistema procesal penal adversarial. Memorias del XXVIII Congreso Colombiano de Derecho Procesal (pp. 65-94). Bogotá: Universidad Libre.

Rodríguez, V. (1998). El debido proceso legal y la convención americana sobre derechos humanos. Liber Amicorum: Héctor Fix-Zamudio (Vol. II, pp. 1295-1328). San José: Ed. Corte Interamericana de Derechos Humanos.

Roxin, C. (2000). Derecho Procesal Penal. (25 ed.) Buenos Aires: Editores del Puerto.

Sampedro, C. (2003). Sujetos procesales dentro del proceso penal colombiano. Acto Legislativo 03 de 2002. En A. J. Cancino (Comp.): Derecho penal y sistema acusatorio en Iberoamérica. Homenaje a Fernando Hinestrosa 40 años de Rectoría 19632003 (pp. 341-349). Bogotá: Universidad Externado de Colombia.

Sampedro, C. (2003a). Bases para la discusión del nuevo sistema procesal penal colombiano. Estado actual de la Justicia colombiana: Bases para la discusión del nuevo 
Sistema Procesal Penal Colombiano (Vol. 2, pp. 289-298). Bogotá: Universidad Externado de Colombia.

Sampedro, J. A. (2008). Los derechos humanos de las víctimas: Apuntes para la reformulación del sistema penal. International Law. Revista Colombiana de Derecho Internacional (12), 353-372.

Sampedro, J. A. (2012). Apuntes para una rehumanización de la justicia penal: en busca de un modelo re-creativo del sistema penal desde las víctimas. Revista Derecho Penal Contemporáneo (41), 133-152.

Sánchez, E. M. (2004). La teoría del delito en un sistema de enjuiciamiento criminal acusatorio. Derecho Penal Contemporáneo: Revista Internacional (7), 107-128.

Sentencia C-022 (1996, enero 23). Demanda de Inconstitucionalidad. M. P. Carlos Gaviria Díaz. Corte Constitucional.

Sentencia C-228 (2002, abril 3). Demanda de Inconstitucionalidad. M. P. Manuel José Cepeda Espinosa y Eduardo Montealegre Lynett. Corte Constitucional.

Sentencia C-591 (2005, junio 9). Demanda de Inconstitucionalidad. M. P. Clara Inés Vargas Hernández. Corte Constitucional.

Sentencia C-1194 (2005, noviembre 22). Demanda de Inconstitucionalidad. M. P. Marco Gerardo Monroy Cabra. Corte Constitucional.

Sentencia C-454 (2006, junio 7). Demanda de Inconstitucionalidad. M. P. Jaime Córdoba Triviño. Corte Constitucional.

Sentencia C-209 (2007, marzo 21). Demanda de Inconstitucionalidad. M. P. Manuel José Cepeda Espinosa. Corte Constitucional.

Sentencia C-343 (2007, mayo 9). Demanda de Inconstitucionalidad. M. P. Rodrigo Escobar Gil. Corte Constitucional.

Sentencia C-396 (2007, mayo 23). Demanda de Inconstitucionalidad. M. P. Marco Gerardo Monroy Cabra. Corte Constitucional.

Sentencia C-118 (2008, febrero 13). Demanda de Inconstitucionalidad. M. P. Marco Gerardo Monroy Cabra. Corte Constitucional.

Sentencia C-536 (2008, mayo 28). Demanda de Inconstitucionalidad. M. P. Jaime Araujo Rentería. Corte Constitucional.

Sentencia C-069 (2009, febrero 10). Demanda de Inconstitucionalidad. M. P. Clara Inés Vargas Hernández. Corte Constitucional.

Sentencia C-616 (2014, agosto 27). Demanda de Inconstitucionalidad. M. P. Jorge Ignacio Pretelt Chaljub. Corte Constitucional.

Sentencia C-471 (2016, agosto 21). Demanda de Inconstitucionalidad. M. P. Alejandro Linares Cantillo. Corte Constitucional. 
Sentencia C-473 (2016, agosto 31). Demanda de Inconstitucionalidad. M. P. Luis Ernesto Vargas Silva. Corte Constitucional.

Sentencia 25920 (2007, febrero 21). Casación. M. P. Javier Zapata Ortíz. Sala de Casación Penal, Corte Suprema de Justicia.

Sentencia 29118 (2008, abril 23). Casación. M. P. Sigifredo Espinosa Pérez. Sala de Casación Penal, Corte Suprema de Justicia.

Sentencia 31614 (2009, julio 22). Casación. M. P. Sigifredo de Jesús Espinosa Pérez. Sala de Casación Penal, Corte Suprema de Justicia.

Sentencia 37596 (2011, diciembre 7). Segunda instancia. M. P. José Luis Barceló Camacho. Sala de Casación Penal, Corte Suprema de Justicia.

Vanegas, M. (2008). Panorama de la problemática a propósito del papel de la víctima en los procedimientos penales de la Ley 600 de 2000 y la Ley 906 de 2004: logros, retrocesos y desafíos. Temas Vigentes en Materia de Dereco Procesal y Probatorio. Homenaje al Dr. Hernando Morales Molina (pp. 360-384). Bogotá: Universidad del Rosario. 